\title{
STUDY OF THE INFLUENCE OF THE RIPENESS DEGREE OF PARSNIP ROOTS AND STORAGE METHOD ON THEIR PRESERVATION
}

\author{
Ludmila Pusik \\ Department of technologies of processing of food production
} Kharkiv Petro Vasylenko National Technical University of Agriculture 44 Alchevsky str., Kharkiv, Ukraine, 61002

Ludmilap@gmail.com

Vladimir Pusik

Department of Agrotechnology and Ecology

Kharkiv Petro Vasylenko National Technical University of Agriculture 44 Alchevsky str., Kharkiv, Ukraine, 61002

kysmish@gmail.com

\section{Nina Lyubymova}

Department of Agrotechnology and Ecology

Kharkiv Petro Vasylenko National Technical University of Agriculture 44 Alchevsky str., Kharkiv, Ukraine, 61002 nina.lioubimova@gmail.com

\section{Veronika Bondarenko}

Laboratory of genetics, biotechnology and quality

V. Y. Yuryev Institute of Plant Production of National Agrarian Academy of Sciences

142 Moskovsky ave., Kharkiv, Ukraine, 61060

zim-hot@rambler.ru

\section{Artur Rozhkov}

Department of Plant growing

Kharkiv National Agrarian University named after V. V. Dokuchaev

Township Dokuchaevsky, Kharkiv region, Kharkivdistrict, Ukraine, 62483 zms19760403@mail.ru

\section{Oksana Sergienko}

Laboratory for the selection of lamb and pumpkin cultures Institute of vegetables and melon growing National Academy of agricultural sciences of Ukraine Township Selektsiyne, Kharkiv region, Kharkiv district, Ukraine, 62478 oksana.sergienko71@ukr.net

\section{Sergey Denisenko}

Department of equipment and engineering of processing and food industries Kharkiv Petro Vasylenko National Technical University of Agriculture 44 Alchevsky str., Kharkiv, Ukraine, 61002 denisenko@gmail.com

Lidiya Kononenko

Department of Crop Production Uman National University of Horticulture

1 Institutska str., Uman, Chercassy reg., Ukraine, 20305 lidiyakononenko@ukr.net 


\section{Abstract}

Sowing parsnip is recommended to be harvested in the stage of technical ripeness that takes place in 120-150 days after sprouts. A ripeness degree cannot be determined by a root size, because in this case planting conditions and agrotechnique play an important role. The aim of the research was to analyze the influence of a vegetation period duration of different sorts of sowing parsnip on formation of chemical composition components and roots preservation to determine the dependence between the content of dry soluble substances and one of dry substances, sugars, saccharose, reducing sugars, ascorbic acid. The research gives a possibility to get roots with the maximal content of chemical composition components and long storage period.

There has been studied the influence of a vegetation period duration of different sorts of sowing parsnip on formation of chemical composition components and roots preservation. The dependence between the content of dry soluble substances and one of dry substances, sugars, saccharose, reducing sugars, ascorbic acid has been determined.

The research has been conducted with parsnip roots of sowing sort Petrik, Student, Boris. There has been studied the influence of a ripeness degree (vegetation period duration) on a quality and preservation of parsnip roots.

Parsnip roots of the sowing sorts Student and Boris are characterized by the most content of the dry substance 27,1-25,4\%, and content of the total sugar 5,7-5,4\%, high content of vitamin C $10,2-10,1 \mathrm{mg} / 100 \mathrm{~g}$. It has been established, that the studied sorts are not inclined to nitrates accumulation, their content varies from 60 to $80 \mathrm{mg} / \mathrm{kg}$ and is lower than the maximally permitted level (MPL $250 \mathrm{mg} / \mathrm{kg}$ ).

There has been established the direct strong connection between the content of the dry substance and sugars content $(\mathrm{r}=0,98)$, nitrates content $(\mathrm{r}=0,80)$ and the middle content with the testing mark $(\mathrm{r}=-0,54)$ and vitamin $\mathrm{C}(\mathrm{r}=0,57)$. The dry soluble substance content has the direct strong connection with the sugars content $(\mathrm{r}=0,99)$, nitrates content $(\mathrm{r}=0,78)$ and middle connection with the content of vitamin $\mathrm{C}(\mathrm{r}=0,46)$ and reverse middle connection with the testing mark $(\mathrm{r}=-0,52)$. The reverse middle connection exists between the sugars content and the testing mark $(\mathrm{r}=-0,52)$ and the direct strong connection with nitrates content $(\mathrm{r}=0,84)$, middle connection with the content of vitamin $\mathrm{C}(\mathrm{r}=0,48)$.

At storage of roots the loss of the mass of dry substances is from $11,5 \%$ at storage in an open box to $6,2-$ in a polyethylene film. The most changes take place in saccharose and monosaccharides, 36,6 and 33,0 \% respectively. The content of vitamin C decreases by $30 \%$ at storage in an open box and by $10 \%$ in a polyethylene film.

The vegetation period duration as 150 days is characterized by the lower sugars content, but at that the ratio saccharose: monosacharides - the most. There has been offered the method of determining the ripeness degree of parsnip roots by the saccharose content. At the technical ripeness the amount of saccharose is $72-75 \%$ of the total amount of sugars.

The optimal ripeness is characterized by deceleration of growing processes, decrease of saccharose accumulation rates, the most ratio of the roots mass to the one of leaves and saccharose to monosugars.

The method of roots storage with p. e. film decreases losses of nutrients of roots and increases the storage duration.

Keywords: parsnip roots, ripeness degree, components of chemical composition, duration of vegetation period.

\section{Introduction}

Parsnip originates from the Mediterranean center [1]. Wild parsnip is spread in many countries of Europe and Asia [2, 3].

The name of the plant originates from the Latin word «pastua» - food, forage, pasture. It was sown specially for forage for pigs, tended on parsnip crops after wintering. The other name «pastinus» - cultivated, farmed soil, because, it is better to cultivate this culture on farmed soils. All European nations called it "parsnip", only Slovaks and Serbs called it a "deer root" [1].

In XVIII century parsnip was cultivated in countries of the Western Europe as a vegetable and forage culture. It was used just like potato: fried, boiled, stewed. In that time first data about round parsnip, named PanaisdeSiam appeared. In 1859 James Bakman created the new sort Student in the King agricultural college. He hybridized cultivated plants with wild parsnip, trying to demonstrate, what local plants can be improved by selective growing. This experiment was so successful that Student became the main sort, cultivated at the end of IXX [4, 5].

In Austria parsnip was used instead of chicory for coffee, in Great Britain and Ireland roots were boiled with hop and added to beer, wine was produced of it too. Dense syrup for replacing honey was boiled of it [6]. 
The expedience of using parsnip and celery as raw materials for getting juices of the high food and biological value has been proved. Parsnip juice is rich in silicon, potassium, phosphorus, chlorine, sulfur [7, 8].

Parsnip roots are used in culinary, in tinned industry, leaves in dermatology - for making decoctions, seeds - in pharmacology. Roots have a pleasant spicy-sweet taste and delicate fragrance that reminds of a mixed bouquet of vegetables of the Celery family - carrot, parsley, caraway, anise, fennel. Parsnip is used as a flavoring in the "white root" composition in soups and sauces, tasty and nourishing main dishes are prepared of it, boiled, stewed, fried and baked. It may be used raw independently or added in salads. Its treating-dietetic properties are widely well-known. It has been established, that its consumption improves digestion, strengthens vascular capillaries, the analgesic and expectorating effects has been noticed. The plant also has toning properties. It is used in folk medicine as a diuretic means and also for exciting sexual activity, improving appetite, against cough, for softening and removing sputum. The modern medicine uses parsnip for treating and preventing cardiovascular diseases. The medical norm of consuming parsnip is $10 \mathrm{~kg}$ for a person per year [9-11].

Studies of the influence of a vegetation period duration on formation of a quality of sowing parsnip roots have not been conducted yet. Sowing parsnip is harvested in the stage of technical ripeness that takes place in 120-180 days after sprouts. Harvesting terms are determined subjectively, based on technical possibilities of a farm and weather conditions. Early harvesting decreases productivity. It is economically profitable for a producer to harvest roots later. Roots, harvested in the stage of optimal ripeness, gain a deeper and longer rest, so, better preservation at the period of winter storage. The ripeness degree of roots cannot be determined by root sizes, by taste properties and consistence of the tissue, because in this case not least role is played by growing conditions and agrotechnique.

So, today introduction of more competitive sorts, with the high content of treating substances, resistant to diseases and pests, able to realize their genetic potential under any vegetation conditions in production gains a topical importance.

The aim of the study was to analyze the influence of a vegetation period duration of different sorts of sowing parsnip on formation of chemical composition components and roots preservation, to determine the dependence between the content of dry soluble substances and one of dry substances, sugars, saccharose, reducing sugars, ascorbic acid. The research gives a possibility to get roots with the maximal content of chemical composition components and long storage period.

\section{Materials and methods of studying the influence of the ripeness degree of parsnip and methods of its storage on its preservation}

The field experiments were conducted at the experimental field in the Eastern part of the Left-bank forest-steppe of Ukraine at the territory of Kharkiv region using drop irrigation. The laboratory ones - at the department of fruit and vegetable growing and storage of KNAU, named after V. V. Dokuchaev, Kharkiv, Ukraine. The climate of the region of the experiments is moderate-continental with unstable moistening and air temperature. The type of soil at the experimental field is typical black earth, weakly washed out, little-humus, heavily-loamy on the carbonate loess.

The field experiments were conducted according to methods, presented in the "Methodology of experiments in vegetable and melon growing" [12]. The studies were conducted with parsnip sorts Petrik, Student and Boris. The way of sowing is wide-rank, scheme of placing plants $45 \times 5 \mathrm{~cm}$ (Fig. 1). The area of an accounting plot is $25,6 \mathrm{~m}^{2}$, reiteration of the experiment - thrice. Parsnip was harvested by the conventional method with vegetation period 140 days, 150 and 175 days. Standard roots were laid for storage. They must be homogenous by the form; diameter in sorts with the oval form is no less $2 \mathrm{~cm}$, in sorts with the round form - no less $3 \mathrm{~cm}$, without defects, fresh, unbroken, not damaged by pests and diseases [13], Table 1 


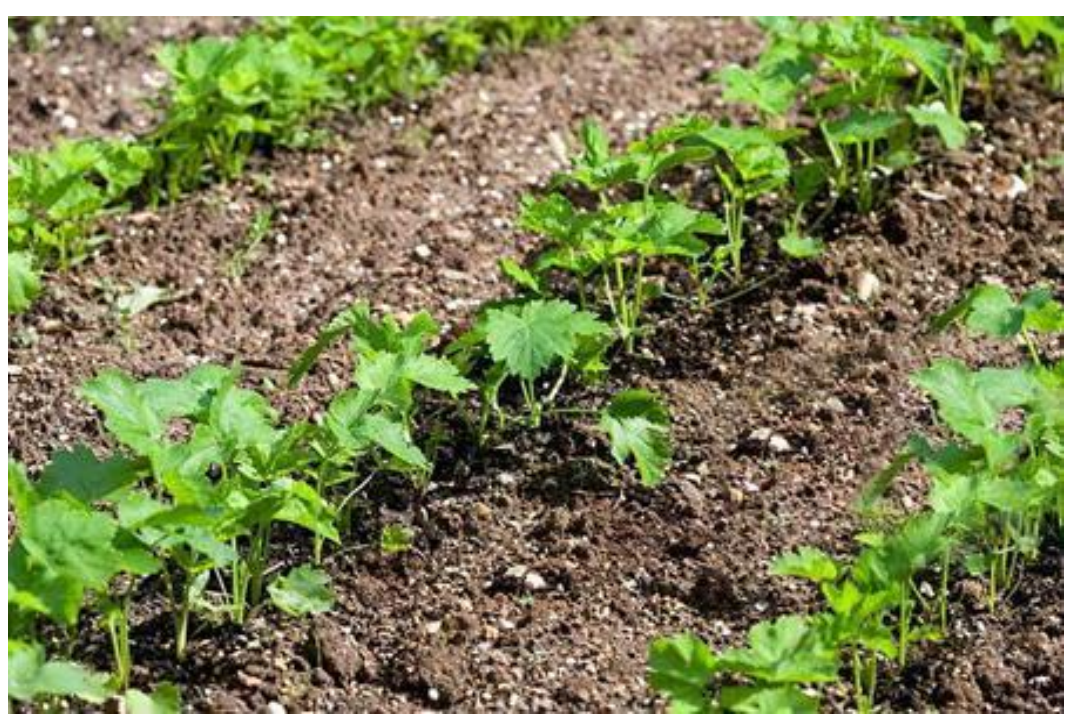

Fig. 1. Parsnip crops

Experiment 1. The influence of the ripeness degree (vegetation period duration) on the quality and preservation of parsnip roots

Experiment 2. Preservation of roots depending on the package method and after-harvesting processing

Table 1

The experimental scheme includes the following variants

\begin{tabular}{cc}
\hline Option number & Packing method of root vegetables \\
\hline 1 variant & Open box, not washed roots (control 1) \\
2 variant & Open box, washed roots (control 2) \\
3 variant & Box with polyethylene films (not washed) \\
4 variant & Box with polyethylene films (washed) \\
5 variant & Perforated bag (not washed) \\
6 variant & Perforated bag (washed) \\
7 variant & Box + sand
\end{tabular}

Roots were stored in a cooling chamber Polair (made by Russia) at temperature $0 \pm 0,5{ }^{\circ} \mathrm{C}$ and relative air humidity 85-90\%. They were stored according to "Methodical recommendations for storing fruits, vegetables and grape. Organization and conduction of studies" [14]. They were stored in open boxes (control), ones with polyethylene films, polyethylene perforated bags with film width $60 \mathrm{mcm}$, in bags with sand layers (sand moisture $15 \%$ ). The observations were made visually, in 1 month after laying for storage. For determining a mass loss at rots storage, each accounting sample (mass $5 \mathrm{~kg}$ ) [15] was weighed, numbered, signed in a journal with a quality characteristic of roots.

There were determined: natural mass losses, mass of roots, damaged by diseases, and sprouted ones; chemical composition components of roots and their change at storage.

Natural losses of mass were determined by the formula:

$$
\mathrm{X}=\frac{\mathrm{A}-\mathrm{B}}{\mathrm{A}} \cdot 100
$$

where $\mathrm{X}$ - mass loss \%; A - mass of products at laying for storage, $\mathrm{g}$; $\mathrm{B}$ - mass of products at the end of storage, $\mathrm{g}$. 
At determining the content of components of the chemical composition for comparing before and after storage, the content of substances at storage was recalculated with correcting the loss mass by the formula:

$$
X=\frac{A \cdot(100-B)}{100},
$$

where $\mathrm{X}$ - actual value of the content of the substance at the end of storage with taking into account the total mass of a product; A - content of the substance at the end of storage; B - mass loss, $\%$

The biochemical studies were conducted by standardized methods, namely: the dry substance content was determined by the method of drying a batch at temperature $105{ }^{\circ} \mathrm{C}$ (SSU ISO 751:2004) [16]; total content of sugars - by Bertrand (SSU 4954:2008) [17]; ascorbic acid (vitamin C) [18C. 249]; nitrates content by SSU 4948:2008 [19].

The statistical processing of the obtained research results was conducted by the method of disperse and correlation-regression analysis and using computer programs «Statistica 6» and MicrosoftExcel2003

The characteristic of the studied sorts of parsnip.

Petrik (Fig. 2). - middle-ripe sort (selection of IVM NAAS). Bundle ripeness after 5070 days, technical one - 84-130. It is used as a spice. It is resistant to peronosporosis. Well-stored. Productivity 50-70 t/he. A root is white, conic, with the gradual narrowing, length $25-40 \mathrm{~cm}$, diameter 4,5-8,6 cm, completely deepened in soil, hardly pulled out. Its surface is even, diameter 2-3 cm. Its flesh and core are white, sometimes with a yellow border. A core is wavy-round, is $44-50 \%$ of the root diameter.

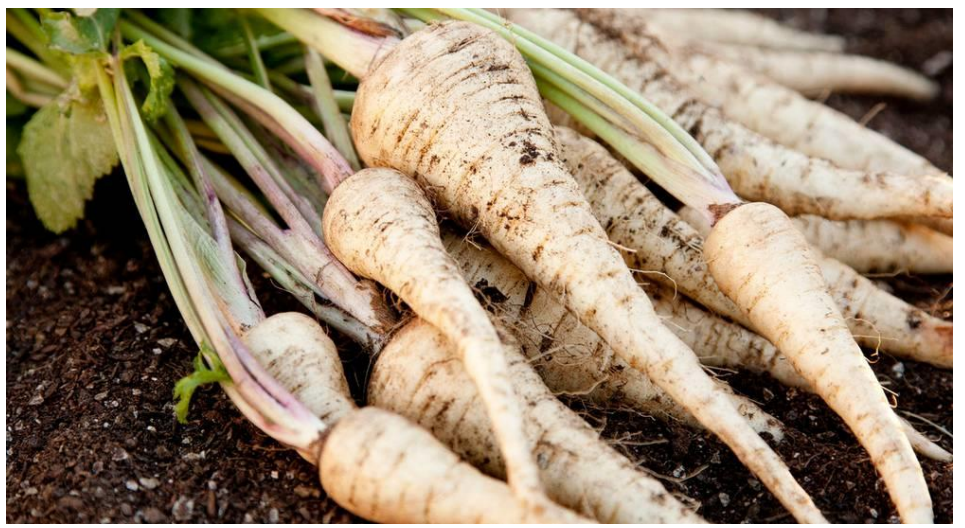

Fig. 2. Outlook of a root Petrik

A rosette of leaves (4-6 units) is right-standing, height 40-65, diameter 64-72 cm. A leaf is feather-divided, its plate is roughly cut in 6-8 long egg-like parts with the dentate edge. A peduncle with length 36-40 cm, round, green, with anthocyanin pigmentation, slightly furred. Roots contain: dry substance $22,2 \%$, sugar $-8,9 \%$, vitamin C - 10,5 mg/100g [20].

Student (Fig. 3) - middle-early sort (made by CeDak, Russia) (vegetation period is 146154 days). A rosette of leaves is semi-spread.

Roots are milky-white, conic, even, mass 100-130 g, with the strong smell and spicy sweat taste, reminding of celery and parsley. Flesh is white, juicy. It is cold-resistant, not demanding for growing conditions. The value of this sort: it contains essential oils, carbohydrates, vitamins $\mathrm{C}, \mathrm{B}_{1}, \mathrm{~B}_{2}, \mathrm{PP}$, carotene, salts of potassium, phosphorus, calcium, magnesium. It favors the proteins exchange, stimulates haemopoiesis, improves vision, regulates the work of the liver and nervous system. It is used fresh and dry as a spicy vegetable supplement to borsch, salads, vegetable and meat dishes, at tinning. At long storage it is better to cover roots with wet sand [21]. 


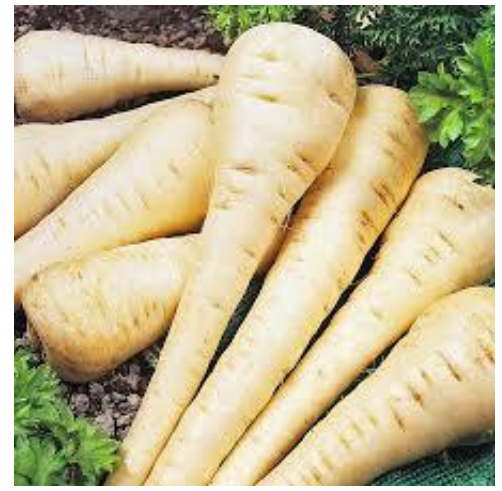

Fig. 3. Outlook of the root Student

Boris (Fig. 4) is a sort of Ukrainian-German selection ("Svytyaz LTD - Satimex Quedlinburg), high-productive and middle-early sort. Ripening terms - from 110 to 120 days. The form of the root is conic, color is creamy. Flesh is juicy, white, dense, with the sweat smell.

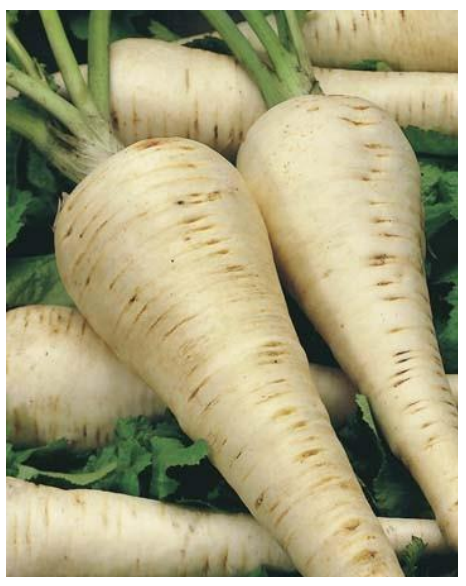

Fig. 4. Outlook of the root Boris

Roots are tasty, used in culinary for processing and fresh. They contain useful microelements, vitamins, have healing properties [21].

\section{Results of the studies of the influence of the parsnip ripeness degree and storage method on its preservation}

It has been established, that accumulation of dry substances and sugar in roots correlate with a mass increment. Synthesis processes take place in roots at growing, sugars concentration increases at the expanse of saccharose, invertase and amylase activity decreases. At the gradual development of the physiological condition, at which ripening processes take place, synthesis processes of dry substances are gradually decelerated. After the maximal accumulation of sugars, their hydrolysis begins [22]. The maximal growth of sugars in parsnip roots is observed in this study at 115 day of the vegetation period (Table 2).

The vegetation period duration 150 days is characterized by the less sugar content, but at that the ratio of saccharose:monosaccharides - the most.

Thus, there may be offered the method of determining the ripeness degree of parsnip roots by the saccharose content. At the technical ripeness the amount of saccharose is $72-75 \%$ of the total amount of sugars.

We think that the technical ripeness is characterized by decelerating growing processes, decreasing rates of saccharose accumulation, most ratio of the roots mass to the mass of leaves and saccharose to monosaccharides. 
Table 2

The content of chemical composition components in parsnip roots depending on the vegetation period duration $\%$

\begin{tabular}{|c|c|c|c|c|c|c|}
\hline $\begin{array}{l}\text { Vegetation } \\
\text { period } \\
\text { duration, days }\end{array}$ & Dry substances & $\begin{array}{l}\text { Monosaccha- } \\
\text { rides }\end{array}$ & Saccharose & Total sugar & $\begin{array}{l}\text { Ratio saccha- } \\
\text { rose:monosac- } \\
\text { charides }\end{array}$ & $\begin{array}{c}\text { Content of } \\
\text { saccharose to } \\
\text { the total sugar }\end{array}$ \\
\hline \multicolumn{7}{|c|}{ Petrik Sort } \\
\hline 65 & 24,08 & 1,92 & 3,14 & 5,00 & 2,58 & 62,1 \\
\hline 85 & 24,58 & 2,10 & 3,49 & 5,76 & 1,66 & 60,6 \\
\hline 95 & 28,56 & 1,98 & 3,70 & 5,78 & 1,86 & 64,0 \\
\hline 115 & 32,46 & 1,85 & 3,93 & 5,88 & 2,12 & 66,8 \\
\hline 150 & 24,10 & 1,20 & 3,70 & 5,00 & 3,08 & 74,0 \\
\hline \multicolumn{7}{|c|}{ Student sort } \\
\hline 65 & 21,97 & 2,73 & 2,85 & 5,58 & 1,04 & 51,0 \\
\hline 85 & 27,77 & 1,83 & 2,99 & 4,98 & 1,63 & 60,0 \\
\hline 95 & 29,11 & 2,23 & 3,69 & 6,04 & 1,65 & 61,1 \\
\hline 115 & 30,57 & 2,28 & 4,25 & 6,55 & 1,66 & 64,8 \\
\hline 150 & 27,10 & 1,40 & 4,20 & 5,70 & 3,00 & 73,7 \\
\hline \multicolumn{7}{|c|}{ Boris sort } \\
\hline 65 & 22,97 & 2,73 & 2,35 & 5,08 & 0,86 & 46,3 \\
\hline 85 & 24,77 & 2,28 & 2,99 & 5,28 & 1,31 & 56,6 \\
\hline 95 & 27,11 & 2,13 & 3,19 & 5,34 & 1,49 & 59,7 \\
\hline 115 & 28,57 & 2,30 & 3,25 & 5,55 & 1,41 & 58,6 \\
\hline 150 & 25,1 & 1,30 & 4,00 & 5,40 & 3,07 & 74,0 \\
\hline
\end{tabular}

Analyzing the obtained data, there have been established certain correlations of biochemical parameters in roots of sowing parsnip sorts. Especially, there is the direct strong connection between the content of the dry substance and sugars content $(\mathrm{r}=0,98)$, nitrates content $(\mathrm{r}=0,80)$ and the middle content with the testing mark $(\mathrm{r}=-0,54)$ and vitamin $\mathrm{C}(\mathrm{r}=0,57)$. The dry soluble substance content has the direct strong connection with the sugars content $(\mathrm{r}=0,99)$, nitrates content $(\mathrm{r}=0,78)$ and middle connection with the content of vitamin $\mathrm{C}(\mathrm{r}=0,46)$ and reverse middle connection with the testing mark $(\mathrm{r}=-0,52)$. The reverse middle connection exists between the sugars content and testing mark $(\mathrm{r}=-0,52)$ and the direct strong connection with nitrates content $(\mathrm{r}=0,84)$, middle connection with the content of vitamin $\mathrm{C}(\mathrm{r}=0,48)$. The direct middle connection $(\mathrm{r}=0,62)$ exists between the content of vitamin $\mathrm{C}$ and the testing mark.

So, the sorts Student and Boris of sowing parsnip roots can be distinguished by the biochemical composition. These sorts are characterized by the highest content of dry substance 27,1$25,4 \%$, and one of total sugar 5,7-5,4\%. There has been also revealed the high content of vitamin C $10,2-10,1 \mathrm{mg} / 100 \mathrm{~g}$. It has been established, that the studied sorts are not inclined to accumulation of nitrates, which content varies from 60 to $80 \mathrm{mg} / \mathrm{kg}$ and was lower than the maximally permitted level (MPL $250 \mathrm{mg} / \mathrm{kg}$ ).

Storage of any juicy products always must be based on their biological characteristic. Parsnip has mechanically dense surface tissues, stored well. Changes of components of the chemical composition of roots depend on the storage method (Table 3). 
Table 3

Changes of components of the chemical composition of roots depending on the storage method

\begin{tabular}{|c|c|c|c|c|c|}
\hline \multirow[b]{2}{*}{ Variant of experiment } & \multicolumn{5}{|c|}{ Content \% } \\
\hline & Dry substances & Sugars & $\begin{array}{l}\text { Manosaccha- } \\
\text { rides }\end{array}$ & Saccharose & Vitamin C \\
\hline \multicolumn{6}{|c|}{ Petrik } \\
\hline At the beginning of storage & 24,1 & 5,0 & 1,3 & 3,7 & 9,9 \\
\hline At the end of storage in boxes & 23,8 & 3,7 & 1,6 & 2,6 & 7,2 \\
\hline At the end of storage in p.e. film & 22,3 & 4,2 & 1,2 & 3,0 & 8,9 \\
\hline \multicolumn{6}{|c|}{ Student } \\
\hline At the beginning of storage & 27,1 & 5,7 & 1,4 & 4,2 & 10,1 \\
\hline At the end of storage in boxes & 24,1 & 3,7 & 0,9 & 2,7 & 7,1 \\
\hline At the end of storage in p.e. film & 25,2 & 4,7 & 1,2 & 3,4 & 9,1 \\
\hline \multicolumn{6}{|c|}{ Boris } \\
\hline At the beginning of storage & 25,8 & 5,4 & 1,3 & 4,0 & 10,2 \\
\hline At the end of storage in boxes & 22,8 & 4,0 & 1,4 & 2,6 & 6,9 \\
\hline At the end of storage in p.e. film & 24,0 & 4,5 & 1,2 & 3,2 & 9,1 \\
\hline
\end{tabular}

At storage of roots the loss of the mass of dry substances is from $11,5 \%$ at storage in an open box to 6,2 - in a polyethylene film. The most changes take place in saccharose and monosaccharides 36,6 and 33,0\% respectively. The content of vitamin $\mathrm{C}$ decreases by $30 \%$ at storage in an open box and by $10 \%$ in a polyethylene film.

At the final stage of storage, as a result of ripening, flesh of vegetables becomes softer, their density decreases. The worsening of quality parameters is conditioned by natural causes (ripening, ageing, growing activity). A damage by diseases takes place under the influence of the environment. The worsening of consumption properties of vegetables results in the decrease of realization. At that total commercial losses may be compared with mass losses and spoilage.

\section{Conclusions}

1. The method of determining the ripeness degree of parsnip roots by the saccharose content has been determined. At the technical ripeness the amount of saccharose is $72-75 \%$ of the total amount of sugars.

2. The sorts Student and Boris of sowing parsnip roots can be distinguished by the biochemical composition. These sorts are characterized by the highest content of dry substance 27,1$25,4 \%$, and one of total sugar 5,7-5,4\%. There has been also revealed the high content of vitamin C $10,2-10,1 \mathrm{mg} / 100 \mathrm{~g}$. It has been established, that the studied sorts are not inclined to accumulation of nitrates, which content varies from 60 to $80 \mathrm{mg} / \mathrm{kg}$ and was lower than the maximally permitted level (MPL $250 \mathrm{mg} / \mathrm{kg}$ ). The sort Student was best by organoleptic parameters. It received the mark of 4,8 points at testing.

3. At storage of roots the loss of the mass of dry substances is from $11,5 \%$ at storage in an open box to 6,2 - in a polyethylene film. The most changes take place in saccharose and monosaccharides 36,6 and 33,0\% respectively. The content of vitamin C decreases by $30 \%$ at storage in an open box and by $10 \%$ in a polyethylene film.

So, such studies of determining the parsnip ripeness degree depending on a vegetation period have not been conducted. At the technical ripeness the amount of saccharose is $72-75 \%$ of the total amount of sugars. The offered method of storing roots with using p.e. film has the practical importance. 
Such studies have been also conducted for cucumbers, melon, vegetable marrows. This one is their continuation. Further promising research directions are the combination of studying the influence of weather conditions of the vegetation period of sowing parsnip on its preservation.

\section{References}

[1] Colombo, M. L., Dalfrà, S., Scarpa, B. (2011). The origin and the tradition of European herbalism for human wellness: from the roots of an ancient approach to modern herbalism. Mediterranean Journal of Nutrition and Metabolism, 4 (3), 173-179. doi: https://doi.org/10.1007/s12349-011-0062-y

[2] Zohary, D., Hopf, M. (2000). Domestication of plants in the Old World. New York, 316.

[3] Stocks, C. (2009). Forgotten Fruits: The stories behind Britain's traditional fruit and vegetables. UK, 320 .

[4] Zohary, D., Hopf, M., Weiss, E. (2012) Domestication of Plants in the Old World. UK, 264. doi: https://doi.org/10.1093/acprof:osobl/9780199549061.001.0001

[5] Kays, S. J. (2011). Cultivated Vegetables of the World: A Multilingual Onomasticon. Wageningen, 828. doi: https://doi.org/10.3920/978-90-8686-720-2

[6] Voigtländer, B., Lattauschke, G. (2013). Wenig bekannte Gemüsearten. Dresden.

[7] Gog, L., Berenbaum, M. R., DeLucia, E. H., Zangerl, A. R. (2005). Autotoxic effects of essential oils on photosynthesis in parsley, parsnip, and rough lemon. Chemoecology, 15 (2), 115-119. doi: https://doi.org/ 10.1007/s00049-005-0294-8

[8] Castro, A., Bergenståhl, B., Tornberg, E. (2012). Parsnip (Pastinaca sativa L.): Dietary fibre composition and physicochemical characterization of its homogenized suspensions. Food Research International, 48 (2), 598-608. doi: https://doi.org/10.1016/j.foodres.2012.05.023

[9] Marčetić, M. D., Lakušić, B. S., Lakušić, D. V., Kovačević, N. N. (2013). Variability of the Root Essential Oils ofSeseli rigidumWaldst. \&Kit. (Apiaceae) from Different Populations in Serbia. Chemistry \& Biodiversity, 10 (9), 1653-1666. doi: https://doi.org/10.1002/cbdv.201200439

[10] Alfaro-Fernández, A., Hernández-Llopis, D., Font, M. I. (2017). Haplotypes of “Candidatus Liberibacter solanacearum" identified in Umbeliferous crops in Spain. European Journal of Plant Pathology, 149 (1), 127-131. doi: https://doi.org/10.1007/s10658-017-1172-2

[11] Gabrovská, D., Ouhrabková, J., Rysová, J., Laknerová, I., Fiedlerová, V., Holasová, M. et. al. (2012). New vegetable and fruit-vegetable juices treated by high pressure. High Pressure Research, 32 (1), 103-113. doi: https://doi.org/10.1080/08957959.2012.664640

[12] Bondarenko, H. L., Yakovenko, K. I. (Eds.) (2001). Metodyka doslidnoi spravy v ovochivnytstvi i bashtannytstvi. Kharkiv: Osnova, 369.

[13] DSTU 8473:2015. Pasternak svizhyi. Tekhnichni umovy.

[14] Dzheneev, S. Yu., Ivanchenko, V. I. (Eds.) (1998). Metodicheskie rekomendacii po hraneniyu plodov, ovoshchey i vinograda. Yalta: In-t vinograda i vina "Magarach", 152.

[15] DSTU ISO 874-2002. Frukty ta ovochi svizhi. Vidbyrannia prob (ISO 874:1980, IDT).

[16] DSTU ISO 751:2004. Frukty, ovochi ta produkty pereroblennia. Metod vyznachennia sukhykh rechovyn, ne rozchynnykh u vodi (kontrolnyi metod).

[17] DSTU 4954:2008. Produkty pereroblennia fruktiv ta ovochiv. Metody vyznachannia tsukriv.

[18] Naychenko, V. M., Zamorska, I. L. (2010). Tehnologiya zberigannya i pererobki plodiv ta ovochiv. Uman: Sochinskiy, 327.

[19] DSTU 4948:2008. Frukty, ovochi ta produkty yikh pereroblennia. Metody vyznachennia vmistu nitrativ.

[20] Sort pasternaka Petrik. Available at: https://prom.ua/p279381149-petrik-semena-pasternaka.html

[21] Samye rasprostranennye sorta pasternaka. "Student". Available at: https://agronomu.com/bok/ 1462-samye-rasprostranennye-sorta-pasternaka.html\#h-id-10

[22] Puzik, L. M., Hordienko, I. M. (2011). Tekhnolohiya zberihannia plodiv, ovochiv ta vynohradu. Kharkiv, 336. 